\title{
is Research Square \\ Cloning and expression of class I chitinase gene from four mangrove species under heavy metal stress
}

\author{
Yue-Yue Zhou \\ South China Sea Institute of Oceanology \\ You-Shao Wang ( $\nabla$ yswang@scsio.ac.cn) \\ South China Sea Institute of Oceanology \\ Cui-Ci Sun \\ South China Sea Institute of Oceanology
}

\section{Research Article}

Keywords: Mangrove plants, Heavy metals, chitinase, Cloning, Gene expression, 3D model

Posted Date: January 18th, 2022

DOI: https://doi.org/10.21203/rs.3.rs-1259203/v1

License: (c) (i) This work is licensed under a Creative Commons Attribution 4.0 International License. Read Full License 


\section{Abstract}

Aims

$\mathrm{Cu}, \mathrm{Pb}$ and $\mathrm{Cd}$ are common heavy metals in mangroves. Objective to clone chitinase I gene in mangrove plants and explore the role of chitinase I gene in plants under heavy metal stress.

\section{Methods}

Homologous cloning and RACE cloning were used to clone chitinase type I gene in mangrove plants, and bioinformatics analysis software was used to analyze and predict gene structure and functional domain. The mRNA expression pattern of chitinase gene in mangrove plants under heavy metal stress was analyzed by real-time quantitative PCR analysis.

\section{Results}

All Four cDNA with a full length of 1092 bp, and an ORF (open reading frame) 831 bp, coding with 276 amino acids, while are differences in the sequences among the four species. Four genes owned signal peptide and were located at vacuole inside the cell. Protein sequence domain analysis indicates that all have the same typical structural characteristics of $\mathrm{GH} 19$ chitinase family. The sequence of $\mathrm{CHI}$ had high similarity to the protein sequences of Camellia fraternal chitinases. Real-time PCR was used to analyze the expression of $\mathrm{CHI}$ under different concentration heavy metal with time of four mangrove species. The gene expression of $\mathrm{CHI} /$ was highly induced in the B.gymnorrhiza leaves than other mangrove species. With the increase of heavy metal stress time, the expression level of B.gymnorrhiza increased continuously.

\section{Conclusion}

Chitinase was induced under heavy metal in mangrove plants, and chitinase plays an active part in heavy metal tolerance in mangrove plants which was located at vacuole inside the cell.

\section{Highlights}

- Chitinase genes (CHI I) were cloned from B.gymnorrhiza, K.obovate, A.marina and R.stylosa for the first time.

- The sequence of $\mathrm{CHI}$ had high similarity to the protein sequences of Camellia fraternal chitinases.

- Protein sequence domain analysis indicated that all had the same typical structural characteristics of GH19 chitinase family.

- The gene expression of $\mathrm{CHI}$ I was highly induced in the B.gymnorrhiza leaves than other mangrove species.

\section{Introduction}

Mangrove wetland is an important ecosystem in the intertidal zone of tropical and subtropical coasts or at the estuary of rivers, and possesses four high characteristics of high productivity, high return rate, high decomposition rate and high resistance as one of the unique marine ecosystems in the world (Wang, 2019; Wang and Gu, 2021). It has important environmental functions and ecological benefits in wind and wave prevention, water purification, biodiversity protection, food supply and habitat (Wang, 2013; Wang, 2019). With the rapid development of modern industry, heavy metal pollution in the offshore environment is becoming more and more serious due to its toxicity and persistence in the water environment for decades. (Kamala-Kannan et al., 2008; Valls and Lorenzo, 2002). Mangrove plants also have certain tolerance to heavy metal when they live in seriously polluted environments for a long time. The adaptation 
mechanisms of mangrove plants to heavy metals include: absorption and efflux of heavy metals (MacFarlane and Burchett, 1999), regionalization (MacFarlane and Burchett, 2000), chelation of organic compounds (Qin, 2007), and scavenging free radicals caused by heavy metal stress through various antioxidant defense systems (Zhang et al., 2007; Huang and Wang, 2010; Sharma and Irudayaraj, 2010) and induced expression of some defense genes (Hall, 2002; Sarowar et al. 2005; Zhang et al., 2012; Huang et al., 2010b).

It has been confirmed that chitinase is one of the related proteins (PR proteins) in plants. Plant chitinases have been divided into at least five classes (I, II, III, IV, and V) based on their sequence similarities (Collinge et al., 1993; Melchers et al., 1994). Most chitinases are also induced by some biological or no-biological factors, such as mechanical damage, chitin, ethylene, salicylic acid, heavy metals, UV, osmotic pressure, low temperature, and drought stress (Kasprzewska, 2003). In normal conditions, chitinase gene expression is very low or not expressed in most higher plants. However, when plants are infected by pathogenic fungi, bacteria or viruses, mechanical trauma or ethylene treatment, their expression activity is greatly increased, and they are often induced to express at the same time with glucanase (EC3.2.1.39), which plays an important role in plant disease resistance and defense response. Peas of three ecological types were treated with $3 \mathrm{mg} / \mathrm{kg}$ Cd sand for one week, then RNA was extracted to clone stress-related genes. The results showed that chitinase gene expression was higher than that of the control (Rivera et al., 2005a). Mycorrhizal and non-mycorrhizal peas were cultured in $100 \mathrm{mg} / \mathrm{kg}$ Cd sand for 3 weeks. Gene expression analysis showed that chitinase, heat shock protein, metallothionein and glutathione synthetase were significantly higher than the control group without Cd treatment (Rivera et al., 2005b). It has been reported that heavy metal ions can induce oxidative stress in plants, indicating that the accumulation of reactive oxygen species in plants under heavy metal stress leads

to the accumulation of $\mathrm{H}_{2} \mathrm{O}_{2}$. The accumulation of $\mathrm{H}_{2} \mathrm{O}_{2}$ diffused and induced the transcription of chitinase gene, the accumulation of corresponding mRNA and the increase of corresponding enzyme activity (Lamb and Dixon, 1997; Fang and Kao, 2000; Tewari et al., 2002). At present, chitinase gene has been cloned from terrestrial plants, such as tobacco (Shinshi et al., 1990), potato (Ancillo et al., 1999), pear (Xiao et al., 2007), rice (Hang et al.,1991; Xu et al. 1996), etc. And studies of regulation are also deeper. However, as a defense protein, it may not directly participate in metal binding, but also plays an important role in metal tolerance of plants, which is little known. In mangrove plants, a class $\mathbb{B}$ chitinase gene was cloned form in A. corniculatum (Wang et al., 2015b). It was also cloned with the full-length cDNA of a class III chitinase gene (AmCHI III) from A. marina(Wang et al., 2015a).

In the paper, the class I chitinase was firstly cloned by using RT-PCR and RACE methods in Bruguiera gymnorrhiza, Rhizophora stylosa, Kandelia obovata, Avicennia marina. Also elucidated for the mRNA expression pattern of $\mathrm{CHI} I$ in response to heavy metal stress.

\section{Material And Methods}

\subsection{Plant material and Treatments}

The six-month-old seedlings of Rhizophora stylosa, Bruguiera gymnorrhiza, Kandelia obovata, and Avicennia marina were purchased from Guangdong Mangrove Ecological Development Co. LTD (China). Each of the species planted 3 seedlings in each pot and divided them into 5 pots (control group CK, C1, C2, C3, C4). Each pot was irrigated with 500 $\mathrm{mL}$ of $1 / 2$ Hoagland solution (containing $10 \% \mathrm{NaCl}$ ) every 3 days. The plants were watered with heavy metal sewage of different pollution levels prepared (Table1). Fresh leaves of plants were harvested after 0 day, 3 day, 7 day, 14 day, 28 day under heavy metal treatment. All the harvested samples were immediately frozen in liquid nitrogen, and stored at $-80^{\circ} \mathrm{C}$ before use. 
Table 1

Heavy metal concentrations in artificial sewage prepared from $1 / 2$ hogland nutrient solution.

\begin{tabular}{|lllllll|}
\hline Heavy metal $(\mathbf{m g} / \mathbf{L})$ & Control group (CK) & $\mathbf{C 1}$ & $\mathbf{C 2}$ & $\mathbf{C 3}$ & $\mathbf{C 4}$ \\
\hline $\mathrm{Cu}^{2+}$ & 0 & 5.0 & 25.0 & 50.0 & 75.0 \\
$\mathrm{~Pb}^{2+}$ & 0 & 1.0 & 5.0 & 10.0 & 15.0 \\
$\mathrm{Cd}^{2+}$ & 0 & 0.2 & 1.0 & 2.0 & 3.0 \\
\hline
\end{tabular}

\subsection{Total RNA isolation and first-strand cDNA synthesis}

Total RNA from leaf was extracted by centrifuging column method, using Tiangen polysaccharide polyphenol plant total RNA extraction kit (Invitrogen, USA), following the manufacturer protocol. Total RNA was dissolved into $30 \mu$ l of RNase free water. Total RNA was quantified by spectrometry, and quality was checked in denatured agarose gels. Firststrand cDNA was synthesized using the PrimeScript TM Reverse Transcriptase (Takara, Dalian, China) following the manufacturer's instructions. Total RNA with $10 \mathrm{mM}$ dNTP in a total volume of $20 \mu \mathrm{L}$ by incubating for $5 \mathrm{~min}$ at $65^{\circ} \mathrm{C}, 1$ $\mathrm{h}$ at $50^{\circ} \mathrm{C}$, and $5 \mathrm{~min}$ at $85^{\circ} \mathrm{C}$ according to the manufacturer's instruction. First-strand cDNA was stored at $-20^{\circ} \mathrm{C}$ before use.

\subsection{Cloning the full-length cDNA of chitinase gene}

The sequences of primers used were shown in Table 2. According to the conserved sequence of chitinase gene in other homologous species, the primers (F1, R1) of the intermediate fragment were designed, and the intermediate fragment was amplified. To obtain a full-length cDNA, two gene-specific primers (GSP1, GSP2) and two nested PCR primers (NGSP1, NGSP2) were deduced from the internal cDNA fragment. Then 5' -and,3' -RACE (rapid amplification of cDNA ends) reactions and PCR procedures were performed using the SMARTer TM RACE Kit (Clontech, USA) according to the manufacturer's instructions. 
Table 2

List of primers for PCR, RACE, Real-time PCR experiments

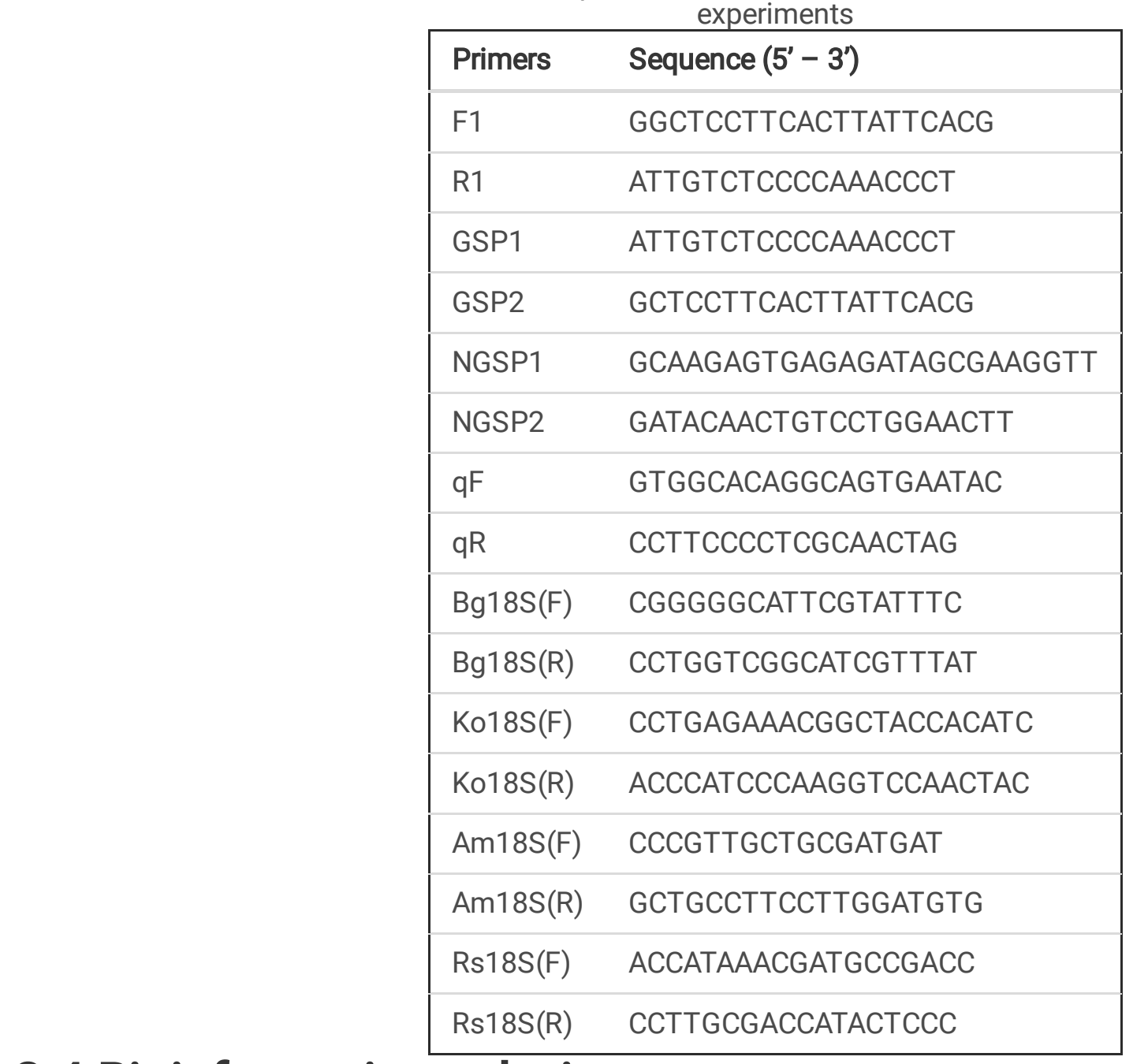

\subsection{Bioinformatic analysis}

The full-length sequence was subjected to bioinformatics analysis using the following software or online tools (Table $3)$, validation of the full-length sequence and analysis of the functional domains. 
Table 3

Methods and the website of bioinformatics analysis

\begin{tabular}{|c|c|}
\hline Function & Tool \\
\hline Spliced sequence alignment. & ApE software \\
\hline Predict the open reading frame & ORF-Finder (https://www.ncbi.nlm.nih.gov/orffinder/) \\
\hline $\begin{array}{l}\text { Predict the molecular weight, theoretical pl and } \\
\text { hydrophilia }\end{array}$ & $\begin{array}{l}\text { ExPASy-Compute-pl/Mw } \\
\text { (http://web.expasy.org/compute_pi/) }\end{array}$ \\
\hline Physical and Chemical Properties of protein & ExPASy-ProtParam (http://web.expasy.org/protparam/) \\
\hline Hydrophilia & ExPASy-ProtScale (http://web.expasy.org/protscale/) \\
\hline Functional site prediction of amino acid sequence & $\begin{array}{l}\text { SoftBerryPSITE (http://www.softberry.com/berry.phtml? } \\
\text { topic= } \\
\text { psite\&group=programs\&subgroup=proloc) }\end{array}$ \\
\hline Protein transmembrane domain analysis & $\begin{array}{l}\text { TMHMM-Server-v.2.0 } \\
\text { (http://www.cbs.dtu.dk/services/TMHMM) }\end{array}$ \\
\hline Predict potential signal peptide cleavage site & $\begin{array}{l}\text { SignalP4.0-Server } \\
\text { (http://www.cbs.dtu.dk/services/SignalP-4.0) }\end{array}$ \\
\hline Analysis of protein structure and function domain & SMART (http://smart.embl-heidelberg.de/) \\
\hline Prediction of protein secondary structure & $\begin{array}{l}\text { SOPMA(https://npsa-prabi.ibcp.fr/cgi- } \\
\text { bin/secpred_sopma.pl) }\end{array}$ \\
\hline Automated 3D structure building & $\begin{array}{l}\text { ExPASy-SWISS-MODEL } \\
\text { (https://www.swissmodel.expasy.org/) }\end{array}$ \\
\hline Multiple sequence alignment & ClustalW2 (http://www.ebi.ac.uk/Tools/msa/clustalw2/) \\
\hline Reconstruct phylogenetic tree & MEGA7 \\
\hline Predict the subcellular localization & ESLPred(http://www.imtech.res.in/raghava/eslpred/) \\
\hline
\end{tabular}

\subsection{Analysis of $\mathrm{CHI} /$ gene expression by real-time quantitative PCR}

Real-time RT-PCR reactions were performed on heavy metal from three replicates in leaf and stem tissue per treatment, performed in twofold replicates for each sample. All data are given in terms of relative mRNA expressed as the mean \pm SD. The Student-Newman-Keuls test $(P<0.05)$ was used to evaluate differences between means of treatments using SPSS 18.0 software. A significant difference is indicated by an asterisk $(P<0.05)$.

\section{Results}

\subsection{The full - length cDNA of $\mathrm{CHI} /$ gene cloning}

As shown in Figure 1A, obvious 28S and 18S bands were observed, indicating good RNA integrity. The UV detection results showed that the OD 260 / OD 280 ratios of the total RNA samples were between 1.8 and 2.2, indicating that the RNA purity was high. Therefore, the proposed RNA has high purity and good quality, which meet the quality requirements of subsequent experiments. With leaf cDNA as the template, a specific fragment of more than $750 \mathrm{bp}$ was obtained by amplification with degenerate primers (Fig. 1B). Blast was performed after sequencing, and the results showed that the fragment was highly homologous to the chitinase gene of other plants $(84.73 \%-74.72 \%)$, indicating that the fragment was the intermediate fragment of $\mathrm{CHII}$ gene. According to the amplified intermediate fragment 
sequence, two pairs of primers for rapid amplification of $3^{\prime}$ and 5 ' ends were designed. After the first and second cycles of $3^{\prime}$ and 5' RACE PCR, the $3^{\prime}$ and 5 ' end-specific fragments of the gene were amplified (Fig. 1C). Sequencing results of these fragments were spliced by MEGAE software, and submitted to NCBI for Blast homology analysis. Finally, we confirmed a correctly encoded nucleotide sequence.

\subsection{Sequence and structure analysis of the full-length cDNA sequence of Chi I}

Cloning and characterization analysis of the full-length CDNA sequence of cDNA sequence analysis indicated that the full-length cDNA fragment encodes a novel basic chitinase gene, designated BgChi, KoChi, AmChi, RsChi (Fig. 2). Four cDNA all were $1092 \mathrm{bp}$, including $831 \mathrm{bp}$ open-reading frame encoding a protein of 276 amino acids. There are different sequences among the four species with 6-30 bases different. BgChi with a predicted molecular mass of $29.50 \mathrm{kDa}$ and a pl of 4.47 (Table 4). KoChi with a predicted molecular mass of $29.59 \mathrm{kDa}$ and a pl of 4.74 (Table 4). AmChi with a predicted molecular mass of $25.57 \mathrm{kDa}$ and a pl of 4.66 (Table 4). RsChi with a predicted molecular mass of 29.47 $\mathrm{kDa}$ and a pl of 4.65 (Table 4). And the Chi I polypeptide is hydrophilic based on the hydrophilicity values (Table 4).

Table 4

Physical and chemical properties of Chi I

\begin{tabular}{|c|c|c|c|c|c|c|c|c|}
\hline Species & $\begin{array}{l}\text { Name } \\
\text { of } \\
\text { gence }\end{array}$ & $\begin{array}{l}\text { Number } \\
\text { of } \\
\text { amino } \\
\text { acids }\end{array}$ & Molecularweight & pl & $\begin{array}{l}\text { The high } \\
\text { content } \\
\text { of amino } \\
\text { acid }\end{array}$ & $\begin{array}{l}\text { Instability } \\
\text { index }\end{array}$ & $\begin{array}{l}\text { Stable } \\
\text { or not }\end{array}$ & $\begin{array}{l}\text { Grand } \\
\text { average of } \\
\text { hydropathicity }\end{array}$ \\
\hline \multirow[t]{2}{*}{$\begin{array}{l}\text { Rhizophora } \\
\text { stylosa }\end{array}$} & \multirow[t]{2}{*}{$\begin{array}{l}\text { Rs } \\
\text { Chi }\end{array}$} & \multirow[t]{2}{*}{ 276аa } & \multirow[t]{2}{*}{$29.47 \mathrm{kDa}$} & \multirow[t]{2}{*}{4.65} & $\begin{array}{l}\text { Gly } 11.2 \% \\
\text { Ala9.1\% }\end{array}$ & \multirow[t]{2}{*}{27.79} & \multirow[t]{2}{*}{$\mathrm{Y}$} & \multirow[t]{2}{*}{-0.186} \\
\hline & & & & & Ser $9.1 \%$ & & & \\
\hline \multirow{3}{*}{$\begin{array}{l}\text { Bruguiera } \\
\text { gymnorrhiza, }\end{array}$} & \multirow{3}{*}{$\begin{array}{l}\mathrm{Bg} \\
\mathrm{Chi}\end{array}$} & \multirow[t]{3}{*}{ 276aa } & \multirow[t]{3}{*}{$29.50 \mathrm{kDa}$} & \multirow[t]{3}{*}{4.74} & Gly $11.2 \%$ & \multirow[t]{3}{*}{27.79} & \multirow[t]{3}{*}{ Y } & \multirow[t]{3}{*}{-0.189} \\
\hline & & & & & Ser $9.1 \%$ & & & \\
\hline & & & & & Ala9.1\% & & & \\
\hline \multirow{3}{*}{$\begin{array}{l}\text { Kandelia } \\
\text { obovata, }\end{array}$} & \multirow{3}{*}{$\begin{array}{l}\text { Ko } \\
\text { Chi }\end{array}$} & \multirow[t]{3}{*}{ 276аa } & \multirow[t]{3}{*}{$29.59 \mathrm{kDa}$} & \multirow[t]{3}{*}{4.69} & Gly $11.2 \%$ & \multirow[t]{3}{*}{27.16} & \multirow[t]{3}{*}{$\mathrm{Y}$} & \multirow[t]{3}{*}{-0.218} \\
\hline & & & & & Ser $9.1 \%$ & & & \\
\hline & & & & & Ala8.7\% & & & \\
\hline \multirow{3}{*}{$\begin{array}{l}\text { Avicennia } \\
\text { marina }\end{array}$} & \multirow{3}{*}{$\begin{array}{l}A m \\
C h i\end{array}$} & \multirow[t]{3}{*}{$276 a a$} & \multirow[t]{3}{*}{$25.57 \mathrm{kDa}$} & \multirow[t]{3}{*}{4.66} & Gly $10.9 \%$ & \multirow[t]{3}{*}{28.75} & \multirow[t]{3}{*}{ Y } & \multirow[t]{3}{*}{-0.155} \\
\hline & & & & & Ser $9.1 \%$ & & & \\
\hline & & & & & Ala $8.3 \%$ & & & \\
\hline
\end{tabular}

The predicted protein all had a structure typical of class I chitinases, consisting of a putative signal peptide region at its N-terminus (amino acid 1-29), a chitin-binding domain (CBD) (amino acid 31-62), and a glycosyl hydrolase catalytic domain (amino acid 76-276) (Fig. 2).

A comparison of the $\mathrm{CHI} \mathrm{I} \mathrm{amino} \mathrm{acid} \mathrm{sequence} \mathrm{of} \mathrm{proteins} \mathrm{in} \mathrm{the} \mathrm{GenBank} \mathrm{database} \mathrm{revealed} \mathrm{that} \mathrm{CHI}$ I shared a high degree of similarity to the Class I chitinases of other plants ( $85.11 \%-76.95 \%$ similarity). BgChi showed very close homology to KoChi and RsChi in Fig. 3\&4. Furthermore, the protein was predicted to be intracellular according to PlantmpLoc (Chou and Shen, 2008). Based on SWISS-MODEL (Schwede et al., 2003) analysis, ribbon cartoon and spacefilling models of $\mathrm{CHI}$ I were presented in Fig. 6. The GH 19 chitinase from rice (Oryza sativa, SMTL id: 3iwr.i.A) (Kezuka 
et al., 2010), which was determined as a modeling template (Fig. 5). Four 3D models of Chi all contained seven a-helix and some random coils (Fig. 5).

\subsection{CHI I mRNA expression in leaf in response to heavy metal}

To realize the expression patterns of $\mathrm{CHI}$ I induced by heavy metal stress, Total RNA was isolated from four mangrove species seedlings leaves after heavy metal stimulation. The effects of heavy metal on the expression of CHI I mRNA in leaves were presented in Fig. 6 and Fig. 7. The real-time quantitative PCR (RT-qPCR) results revealed that the expression patterns of four mangrove species were very different. Chitinases were expressed in B.gymnorrhiza, K.obovate and A.marina under heavy metal stress. Under heavy metal stress, the gene expression of $\mathrm{CHI} I$ was highly induced in the B.gymnorrhiza leaves. While the expression level of R.stylosa was basically 0 . The highest gene expression of B.gymnorrhiza was 55.23 times that of the control group. The highest gene expression level of K.obovate was 10.17 times that of the control group. The highest gene expression of A.marina was 14.36 times that of the control group. With the increase of heavy metal concentration, the gene expression of B.gymnorrhiza increased first and then decreased. The gene expression of $K$. obovate increased with the increase of heavy metal concentration.

After 3 days of heavy metal stress, $\mathrm{CHI}$ I gene expression was first induced in B.gymnorrhiza. After 7 days of heavy metal stress, the expression of A.marina was the highest. After 28 days of heavy metal stress, the expression of B.gymnorrhiza was the highest. With the increase of heavy metal stress time, the expression level of B.gymnorrhiza increased continuously, and the gene expression level of K.obovate remained stable.

\section{Discussion}

\subsection{Cloning and structural characterization analysis of $\mathrm{CHI}$}

Plant chitinase precursors generally contain a N-terminal signal region, a catalytic region and a C-terminal extension region. Some have chitin-binding do-rich $(\mathrm{CBD})$ in cysteine after the N-terminal signal region, which is connected with the catalytic region by the variable cross-linking region (Graham and Sticklen, 1994). The GH19 family consists of all I, II and IV chitinases (Santos et al., 2008). In this study, chitinase genes (CHII) were cloned from B.gymnorrhiza, K.obovate, A.marina and R.stylosa for the first time(Fig. 2). Using SMART software to predict chitinase protein structures including signal region, $\mathrm{CBD}$ and GH19 chitinase family catalytic domain. Most of them are small molecular proteins with molecular weight between 25 and $35 \mathrm{kDa}$ (Arakane and Koga, 1999). In our study, we found that all four cDNA were $1092 \mathrm{bp}$, including $831 \mathrm{bp}$ open-reading frame encoding a protein of 276 amino acids with molecular weight between 25.57 and $29.59 \mathrm{kDa}$ (Table 4). As a result, bioinformatics analysis revealed that BgChi, KoChi, AmChi, RsChi were a typical class I chitinase with the characteristic catalytic structure of chitinase.

The sequences among the four species are different (Fig. 2\&3, Table 4). Compared with R.stylosa, there is one amino acid difference in B.gymnorrhiza, five amino acid differences in K.obovate, and ten amino acid differences in A.marina (Fig. 3). BgChi showed very close homology to KoChi and RsChi in Fig. 4. We know that B.gymnorrhiza, K.obovate and R.stylosa belong to the same family of Rhizophora, while A.marina belongs to Verbenaceae. Phylogenetic tree analysis indicated that $\mathrm{CHI}$ had the closest relationship with chitinase in Camellia fraternal (75.05\% similarity) (Fig. 8).

Phylogenetic clustering results are more consistent with the traditional morphological classification results. $\mathrm{CHI} /$ of A.corniculatum exhibited very close homology to the class I chitinase from Camellia sinensis (69\% similarity) (Wang et al., 2015a). Camellia fraternal and Camellia sinensis are similar species. A.corniculatum is one species of mangroves.

Iseli et al. studied class I chitinase genes in tobacco suggesting that CBD is not catalytic and antifungal activity is necessary, but binding chitin is necessary and has enhanced antibacterial effect (Iseli et al., 1993). CBD of class I 
chitinases that acted as allergens in avocados and chestnuts may be associated with allergic reactions (Blanco et al.,1999). Therefore, we suppose that some of the cysteine residues in $\mathrm{CHI}$ I are essential for metal homeostasis in a harsh environment such as heavy metal stress.

Chitinases in plants are encoded by single genes. Both secreted outside and localized inside. In this study, the $\mathrm{CHI}$ protein was predicted to locate on vacuoles in cells according to Plant-mpLoc (Chou and Shen, 2008). The CHI protein was a hydrophilic protein, so we speculated about the possibility of transmembrane.

\subsection{Expression of $\mathrm{CHI} /$ in leaves in response to heavy metal}

Plant chitinases are induced by a series of abiotic stresses, including osmotic stress, salt stress, low temperature stress, mechanical damage and heavy metal stress (Loon et al., 2006). Class I chitinase gene was induced by mechanical damage in Ficuscarica (Kim et al., 2003). Chitinase genes in Viciafaba, Barley, Maize and Soy bean were induced by lead, arsenic and cadmium, indicating that this enzyme could prevent heavy metal toxicity (Békésiová et al., 2008; Keulen et al., 2008). In our experiment, in addition to R.stylosa, the $\mathrm{CHI}$ of the other three mangrove plants were induced by heavy metal stress. In terrestrial plants, the effects of chitinases have been studied to varying degrees. Stress associated proteins, like peroxidase and chitinase were also found associated with $\mathrm{Hg}$ in the vines (Spisso et al., 2018). CHI has chitinase activity, and may be involved in the decomposition and metabolism of the cell wall macromolecule catabolic process and carbohydrate metabolic process (Spisso et al., 2018). Plant chitinases not only play a role in metal metabolism, but also in detoxification of excess heavy metals. Heavy metal accumulation can disturb the absorption and distribution of large amounts of elements and trace elements in plants and cause plant death. Due to long-term environmental selection and adaptive evolution, plants have developed tolerance mechanisms to reduce or avoid heavy metal toxicity (Zhang and Shu, 2006). Cd treatment could induce up-regulation of chitinase, heat shock protein (HSP70) and other genes (Rivera et al., 2005a). Mycorrhizal peas and non- Mycorrhizal peas after three weeks of culture on $100 \mathrm{mg} / \mathrm{kg}$ Cd sand, the gene expression analysis showed that chitinase, heat shock protein, metallothionein and glutathione synthase were significantly higher than those in the control group without $\mathrm{Cd}$ treatment (Rivera et al., 2005b).

Heavy metal $\mathrm{Cu}, \mathrm{Cd}$ and $\mathrm{Pb}$ are important pollutants in the environment, and often exist in nature compound pollution $(\mathrm{Gu}, 2003)$. Under combined pollution, the tolerance mechanism of plants is more complex, and it is more necessary to study the effect of combined pollution on plants and the response of plants to combined pollution. The results of this study showed that the expression of $\mathrm{CHI}$ I was significantly induced in leaves of B.gymnorrhiza, K.obovate and A.marina under combined heavy metal. Real-time quantitative results can be obtained four mangrove expression patterns are not the same under heavy metal stress. The maximum expression levels in leaves B.gymnorrhiza, K.obovate and A.marina were 55.23, 10.17 and 14.36 times that of the control, respectively. The gene expression of $\mathrm{CHI}$ I was highly induced in the B.gymnorrhiza leaves than other mangrove species. With the increase of heavy metal stress time, the expression level of B.gymnorrhiza increased continuously. R.stylosa is tolerant to heavy metal and has an antioxidant enzyme system(Zhou et al, 2021 ), while chitinase has little effect. Chitinases are located in vacuoles in cells and have the possibility of transmembrane. Chitinase expression was induced after heavy metals entered the leaves, and the expressed proteins may act on metal transporters in the cell membrane to reduce the absorption of heavy metals. That may reduce the accumulation of heavy metals on cell damage (Fig. 9). Mangrove more tolerable to the heavy metal and it can be used as a potential phytoremediator in heavy metal polluted marine wetlands.

\section{Conclusion}

A new chitinase (CHI) gene was cloned from Bruguiera gymnorrhiza, Rhizophora stylosa, Kandelia obovata, Avicennia marina. And structure includes signal peptide region at its N-terminus, a chitin-binding domain (CBD), and a glycosyl 
hydrolase catalytic domain. $\mathrm{CHI} /$ belongs to glycosidase family 19 . The chitinase gene sequences of four mangrove species were different. $\mathrm{CHI} /$ transcripts differentially express in four mangrove species under heavy metal. The gene expression of $\mathrm{CHI}$ / was highly induced in the B.gymnorrhiza leaves than other mangrove species. This study will provide more details on the molecular mechanisms or a scientific basis for coastal wetland with heavy metal environmental remediation with mangrove plants.

\section{Declarations}

\section{Acknowledgments}

This research was supported by the National Natural Science Foundation of China (No. 41876126 and No.U1901211), International Partnership Program of Chinese Academy of Sciences (No. 133244KYSB20180012), the National Key Research and Development Plan (No. 2017FY100700), Key Special Project for Introduced Talents Team of Southern Marine Science and Engineering Guangdong Laboratory (Guangzhou) (No.GML2019ZD0305) and the Strategic Priority Research Program of the Chinese Academy of Sciences (No. XDA23050200 and XDA19060201).

\section{Credit Author Statement}

Yue-Yue Zhou: Methodology, Software\Data curation, Writing-Original draft preparation. Visualization, Software, Validation $₫$ Writing- Reviewing and Editing.

You-Shao Wang]Conceptualization, Supervision, Writing- Reviewing and Editing.

Cui-Ci Sun囚lnvestigation and Writing- Reviewing.

\section{Declaration of Interest Statement}

Conflict of Interest: All authors declare that they have no conflict of interest in this study.

Declaration of Interest: The authors declare that they have no known competing financial interests or personal relationships that could have appeared to influence the work reported in this paper.

Funding Source Declaration: It is contained for all funding or research grants received the course of study and assembly of the manuscript.

\section{References}

1. Ancillo G, Witte B, Schmelzer E, Kombrink E (1999) A distinct member of the basic (class I) chitinase gene family in potato is specifically expressed in epidermal cells. Plant Mol Biol 39:1137-1151. https://doi.org/10.1023/A:1006178425803

2. Arakane Y, Koga D (1999) Purification and characterization of an ovel chitinase isozyme from yam tuber. Biosci Biotech Bioch 63(11):1895-1901. https://doi.org/10.1271/bbb.63.1895

3. Békésiová B, Hraška Å, Libantová J, Jana Moravčíková J, Matušíková I (2008) Heavy-metal stress induced accumulation of chitinase isoforms in plants. Mol Biol Rep 35(4):579-588. https://doi.org/10.1007/s11033-0079127-x

4. Blanco C, Diaz PA, Collada C et al (1999) Class I chitinases as potential panallergens involved in the latex-fruit syndrome. J Allergy Clin Immunol 103(3):507-513. https://doi.org/10.1016/S0091-6749(99)70478-1 
5. Chou KC, Shen HB (2008) Cell-PLoc: A package of web-servers for predicting subcellular localization of proteins in various organisms. Nat Protoc 3:153-162. https://doi.org/10.1038/nprot.2007.494

6. Collinge DB, Kragh KM, Mikkelsen JD et al (1993) Minireview: Plant chitinases. Plant J 3(1-5):31-409

7. Fang WC, Kao CH (2000) Enhanced peroxidase activity in rice leaves in response to excess iron, copper and zinc. Plant Sci 158:71-76. https://doi.org/10.1016/S0168-9452(00)00307-1

8. Graham LS, Sticklen MB (1994) Plant chitinases. Can J Bot 72(72):1057-1083. https://doi.org/10.1139/b94-132

9. Gu JG, Zhou QX, Wang X (2003) Ways to control soil heavy metal pollution and its research progress. Application base Journal of Basic and Engineering Science 11(2):143-151

10. Hall J (2002) Cellular mechanisms for heavy metal detoxification and tolerance. J Exp Bot 366:1-11. https://doi.org/10.1093/jexbot/53.366.1

11. Hoell IA, Klemsdal SS, Vaaje KG et al (2005) Overexpression and characterization of a novel chitinase from Trichoderma atroviride strain P1. Biochim Biophys Acta 1748(2):180-190.

https://doi.org/10.1016/j.bbapap.2005.01.002

12. Huang GY, Wang YS (2009) Expression analysis of type 2 metallothionein gene in mangrove species (Bruguiera gymnorrhiza) under heavy metal stress. Chemosphere77(7):1026-

1029.hppts://doi.org/10.1016/j.chemosphere.2009.07.073

13. Huang GY, Wang YS (2010a) Expression and characterization analysis of type 2 metallothionein from grey mangrove species (Avicennia marina) in response to metal stress. Aquat Toxicol 99(1):86-92.

https://10.1016/j.aquatox.2010.04.004

14. Huang GY, Wang YS (2010b) Physiological and biochemical responses in the leaves of two mangrove plant seedlings (Kandelia candel and Bruguiera gymnorrhiza) exposed to multiple heavy metals. J Hazard Mater 182(13):848-854. https://doi.org/10.1016/j.jhazmat.2010.06.121

15. Huang JK, Wen L, Swegle M et al (1991) Nucleotide sequence of a rice genomic clone that encodes a class I chitinase. Plant Mol Biol 16:479-480. https://doi.org/10.1007/BF00023999

16. Iseli B, Boller T, Neuhaus JM (1993) The N-terminal cysteine-rich domain of tobacco class I chitinase is essential for chitin binding but not for catalytic or antifungal activity. Plant Physiol 103(1):221-226.

https://doi.org/10.1104/pp.103.1.221

17. Kamala KS, Prabhu D, Batvari B et al (2008) Assessment of heavy metals ( $\mathrm{Cd}, \mathrm{Cr}$, and $\mathrm{Pb}$ ) in water, sediment, and seaweed (Ulva lactuca) in the Pulicat Lake, Southeast India. Chemosphere 71(7):1233-1240.

.https://doi.org/10.1016/j.chemosphere.2007.12.004

18. Kasprzewska A (2003) Plant chitinases-regulation and function. Cellular Biology Letters 8(3):809-824

19. Keulen HV, Wei R, Cutright TJ (2008) Arsenate-induced expression of a class â...ç chitinase in the dwarf sunflower Helianthus annuus. Environ Exp Bot 63(1-3):281-288. https://doi.org/10.1016/j.envexpbot.2007.11.012

20. Kezuka Y, Kojima M, Mizuno R et al (2010) Structure of full-length class I chitinase from rice revealed by X-ray crystallography and small-angle X-ray scattering. Proteins: structure Funct Bioinf 78:2295-2305. https://doi.org/10.1002/prot.22742

21. Kim JK, Jang IC, Wu R et al (2003) Co-expression of a modified maize ribosome-inactivating protein and a rice basic chitinase gene in transgenic rice plants confers enhanced resistance to sheath blight. Transgenic Res 12(4):475-484. .https://doi.org/10.1023/A:1024276127001

22. Lamb C, Dixon RA (1997) The oxidative burst in plant disease resistance. Annu Rev Plant Physiol Plant Mol Biol 48:251-275. https://doi.org/10.1146/annurev.arplant.48.1.251

Page 11/19 
23. Loon LCV, Rep M, Pieterse CMJ (2006) Significance of inducible defense-related proteins in infected plants. Annu Rev Phytopathol 44(1):135-162. https://doi.org/10.1146/annurev.phyto.44.070505.143425

24. MacFarlane G, Burchett M (1999) Zinc distribution and excretion in the leaves of the grey mangrove, Avicennia marina. (Forsk) Vierh Environmental and Experimental Botany 41(2):167-175. https://doi.org/10.1016/S00988472(99)00002-7

25. MacFarlane G, Burchett M (2000) Cellular distribution of copper, lead and zinc in the grey mangrove, Avicennia marina. (Forsk) Vierh Aquatic Botany 68(1):45-59. https://doi.org/10.1016/S0304-3770(00)00105-4

26. Melchers LS, Apothekerde GM, Knaap JA et al (1994) A new class of tobacco chitinases homologous to bacterial exo-chitinases displays antifungal activity. Plant J 5:469-480. https://doi.org/10.1046/j.1365-

313X.1994.05040469.x

27. Qin T (2006) Soluble Sugar and Proline Contents of Kandelia obovata Seedling Leaves on Cd Responses to stress. J Ecol 26(10):3366-3371

28. Santos P, Fortunato ARA, Pawlowski K (2008) Chitinases in root nodules. Plant Biotechnol 25(3):299-307. https://doi.org/10.5511.plantbiotechnology.25.299

29. Rivera BF, Metwally A, Martin LF et al (2005a) Molecular responses to cadmium in roots of Pisum sativum L. Water Air \& Soil Pollution 168(1):171-186. https://doi.org/10.1007/s11270-005-1247-0

30. Rivera BF, van Tuinen D, Martin LF et al (2005b) Molecular changes in Pisum sativum L. roots during arbuscular mycorrhiza buffering of cadmium stress. Mycorrhiza 16(1):51-60. https://doi.org/10.1007/s00572-005-0016-7

31. Sarowar S, Kim YJ, Kim EN et al (2005) Overexpression of a pepper basic pathogenesis-related protein 1 gene in tobacco plants enhances resistance to heavy metal and pathogen stresses. Plant Cell Rep 24:216-224. https://doi.org/10.1007/s00299-005-0928-x

32. Schwede T, Kopp J, Guex N et al (2003) SWISS-MODEL: an automated protein homology-modeling server. Nucleic Acids Res 31:3381-3385. https://doi.org/ 10.1073/pnas.0807484105

33. Sharma C, Irudayaraj V (2010) Studies on heavy metal(Arsenic)tolerance in a mangrove fern Acrostichum Aureum L. Journal of Basic and Applied Biology 4(3):143-152

34. Shinshi H, Neuhas JM, Ryals J et al (1990) Structure of a tobacco endochitinase gene:evidence that different chitinase genes can arise by trans-position of sequences encoding a cysteine rich domain. Plant Mol Biol 14:357368. https://doi.org/10.1007/BF00028772

35. Spisso A, Verni E, Nahan K, Martinez L, Landero J, Pacheco P (2018) The metabolic effects of mercury during the biological cycle of vines (Vitis vinifera). Biometal 31(2):243-254. https://doi.org/ 10.1007/s10534-018-0084-8

36. Tewari RK, Kumar P, Sharma PN, Bisht SS (2002) Modulation of oxidative stress responsive enzymes by excess cobalt. Plant Sci 162:381-388. https://doi.org/10.1016/S0168-9452(01)00578-7

37. Valls M, Lorenzo VD (2002) Exploiting the genetic and biochemical capacities of bacteria for the remediation of heavy metal pollution. FEMS Microbiol Rev 26:327-338. https://doi.org/10.1111/j.1574-6976.2002.tb00618.x

38. Wang LY, Wang YS, Cheng $\mathrm{H}$ et al (2015b) Cloning the Aegiceras corniculatum class â... chitinase gene (AcCHlâ... ) and the response of AcCHlâ... mRNA Expression to cadmium stress. Ecotoxicology 24(7-8):1705-1713.

https://doi.org/ 10.1007/s10646-015-1502-0

39. Wang LY, Wang YS, Zhang JP et al (2015a) Molecular cloning of class â...ç chitinase gene from Avicennia marina and its expression analysis in response to cadmium and lead stress. Ecotoxicology 24(7-8):1697-1704.

https://doi.org/ 10.1007/s10646-015-1501-1

40. Wang YS (2013) Restoration and evaluation technology of mangrove ecosystem. The Science Publishing Company, Beijing, China

Page 12/19 
41. Wang YS (2019) Molecular ecology of mangroves. The Science Publishing Company, Beijing, China

42. Wang YS, Gu JD (2021) Ecological responses, adaptation and mechanisms of mangrove wetland ecosystem to the global climate change and anthropogenic activities. International Biodeterioration Biodegradation 162:105248. https://doi.org/10.1016/j.ibiod.2021.105248

43. Xiao YH, Li XB, Yang XY et al (2007) Cloning and characterization of a balsam pear class I chitinase gene (Mcchit1) and its ectopic expression enhances fungal resistance in transgenic plants. Biosci Biotechnol Biochem 71(5):1211-1219. https://doi.org/10.1271/bbb.60658

44. Xu Y, Zhu Q, Panbangred W et al (1996) Regulation, expression and function of a new basic chitinase gene in rice (Oryza sativa L.). Plant Mol Biol 30:387-401. https://doi.org/10.1007/bf00049319

45. Zhang FQ, Wang YS, Lou ZP et al (2007) Effect of heavy metal stress on antioxidative enzymes and lipid peroxidation in leaves and roots of two mangrove plant seedlings (Kandelia candel and Bruguiera gymnorrhiza). Chemosphere 67:44-50. https://doi.org/ 10.1016/j.chemosphere.2006.10.007

46. Zhang FQ, Wang YS, Sun CC et al (2012) A novel metallothionein gene from a mangrove plant Kandelia candel. Ecotoxicology 21(6):1633-1641. https://doi.org/10.1007/s10646-012-0952-x

47. Zhang J, Shu WS (2006) Mechanism of plant tolerance to heavy metal cadmium. Journal of Plant Physiology and Molecular Biology 32(1):1-8

48. Zhou YY, Wang YS, Inyang AI (2021) Ecophysiological differences between five mangrove seedlings under heavy metal stress. Mar Pollut Bull 172. https://doi.org/10.1016/j.marpolbul.2021.112900

\section{Figures}
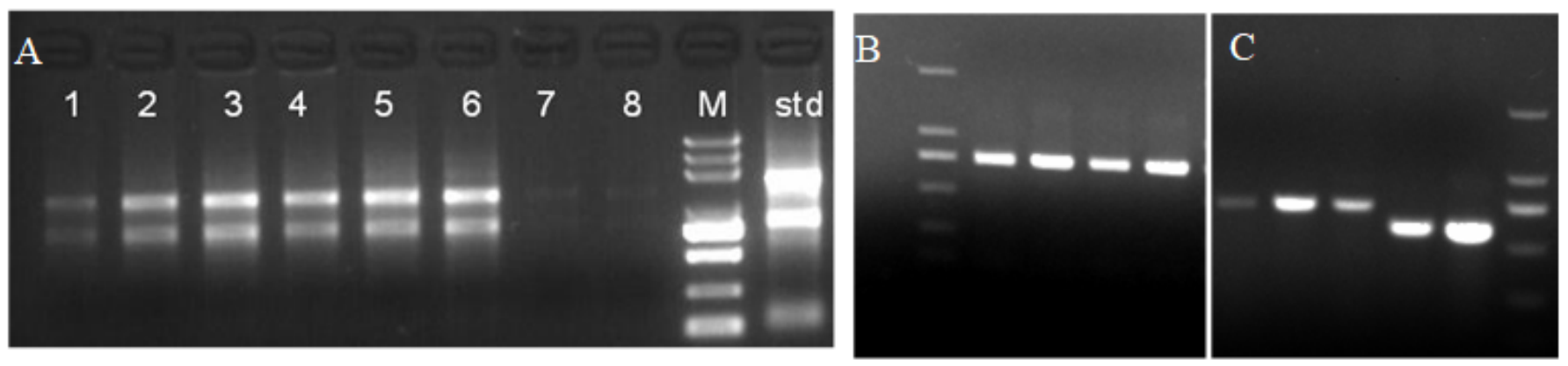

\section{Figure 1}

Agarose gel electrophoresis of total RNA (A), CHI I fragment (B), and PCR products of $3^{\prime}$ or $5^{\prime}$ RACE(C). M: DNA Marker DL5000. 


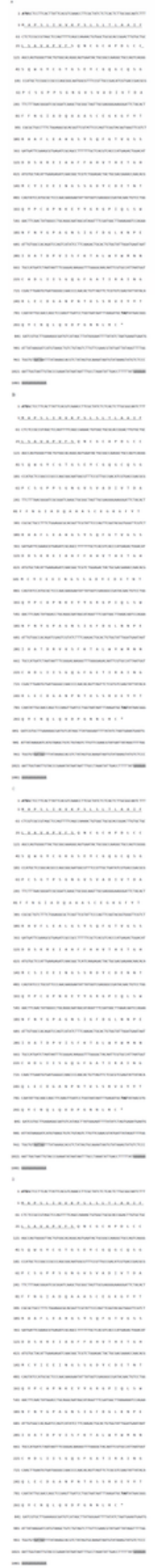

\section{Figure 2}

The nucleotide sequence of the full-length CDNA and the deduced amino acid sequence of the $\mathrm{CHI}$ I gene. The start codon ATG and stop codon TAG are shown in bold italic, the predicted amino acid sequence is shown in one-letter code under the DNA sequence. The AATAA-box is highlighted in gray, the poly $(A)$ tail is highlighted in gray $(A: B g C h i, B$ : KoChi, C: AmChi, D: RsChi) 
BgChII : MAPSLIHVKPSLSLTLAAIFLSAVAPVFSQNCGCAPDLCCSQWGYCGTGSEYCGQGCQSGPCSGPPSNG

KOChII : MAPSLIHVKPSLSLTLAAIFLSAVAPVFSQNCGCAPDLCCSOWGYCGTGSEYGQGCQSGPCSGPSGNG

RSChII : MAPSLIHVKPSLSLTLAAIFLSAVAPVFSQNCGCAPDLCCSQWGYCGMGSEYCGQGCQSGPCSGPPSGNG

AmChiI : MAPSLIHVKPSLSLTLAAIFIVAVAPVFSQNCGCAPDLCCSQWGYCGKGSEYCGQGCQSGPCSGTPSGNG MAPSLIHVKPSLSLTLAAIFLSAVAPVFSQNCGCAPDLCCSOWGYCG TGSEYGQGCQSGPCSGPPSGNG

80

100

120

140

BgChiI : VSVADIVTDAFFNGIADQAAASCEGKGFYTRAAFLEAHGSYSQFGTVGSSDDSKREIAAFFAHVTHETGH KOChiI : VSVADIVTDAFFNGIADQAAASCEGKGFYTRA FLEAHGSYSQFGTVGSSDDSKREIAAFFAHVTHETGH RSChiI : VSVADIVTDAFFNGIADQAAASCEGKGFYTRA FLEAHGSYSQFGTVGSSDDSKREIAAFFAHVTHETGH AmChII : VSVADIVTDAFFNGIADQAAASCEGKGFYTRAVELEAIGSYSQFGTVGSSDDSKREIAAFFAHVTHETGH VSVADIVTDAFFNGIADQAAASCEGKGFYTRAaFLEAhGSYSQFGTVGSSDDSKREIAAFFAHVTHETGH

BgChII : MCYIEEINGSSGDYCDETNTQYPCA PNKEYYGRGPIQLSWNFNYGPAGNSIGFDGIKNPEIVATDPVISF KOChII : MCYIEEINGSSGDYCDEINTQYPCA PNKEYYGRGPIQLSWNFNYGPAGNSIGFDGINNPEIVATLRVVSF RsChII : MCYIEEINGSS DYCDEINTQYPCA PNKEYYGRGPIQLSWNFNYGPAGNSIGFDGIKNPEIVATDPVISF AmChiI : MOSIEEINGSSRDYCDENNTQYPOVPNKEYYGRGPIQLSWNFNYGPAGNSIGFDGINNPEIVATDPVISF MCYIEEINGSSgDYCDE tNTQYPCAPNKEYYGRGPIQLSWNFNYGPAGNSIGFDGL NPEIVATDPViSF

$$
220 \quad * \quad 240 \quad * \quad 260
$$

BgChiI : KTALWYWMNNCHDLIISGQGFGATIRAINGRLECDGANPNTVSSRVEYYTQYCNQLQVDPGNNLRC KOChII : KTALWYWMNNCHDLIISGQGFGETIRAINGRLECDGANPNTVSSRVEYYTQYCNQLQVDPGNNLRC RSChII : KTALWYWMNNCHDLIISGQGFGATIRA INGCLECDGANPNTVSSRVEYYTQYCNQLQVDPGNNLRC

AmChiI : KTALWYWMNNCHDLIISGQGFGATIRAINGQLECDGANPNTVSSRVEYYTQYCNQLQVDPGNNLRC KTALWYWMNNCHDIIISGQGFGaTIRAING LECDGANPNTVSSRVEYYTQYCNQLQVDPGNNLRC

\section{Figure 3}

Multiple alignment of the amino acid sequences of four Chi I protein

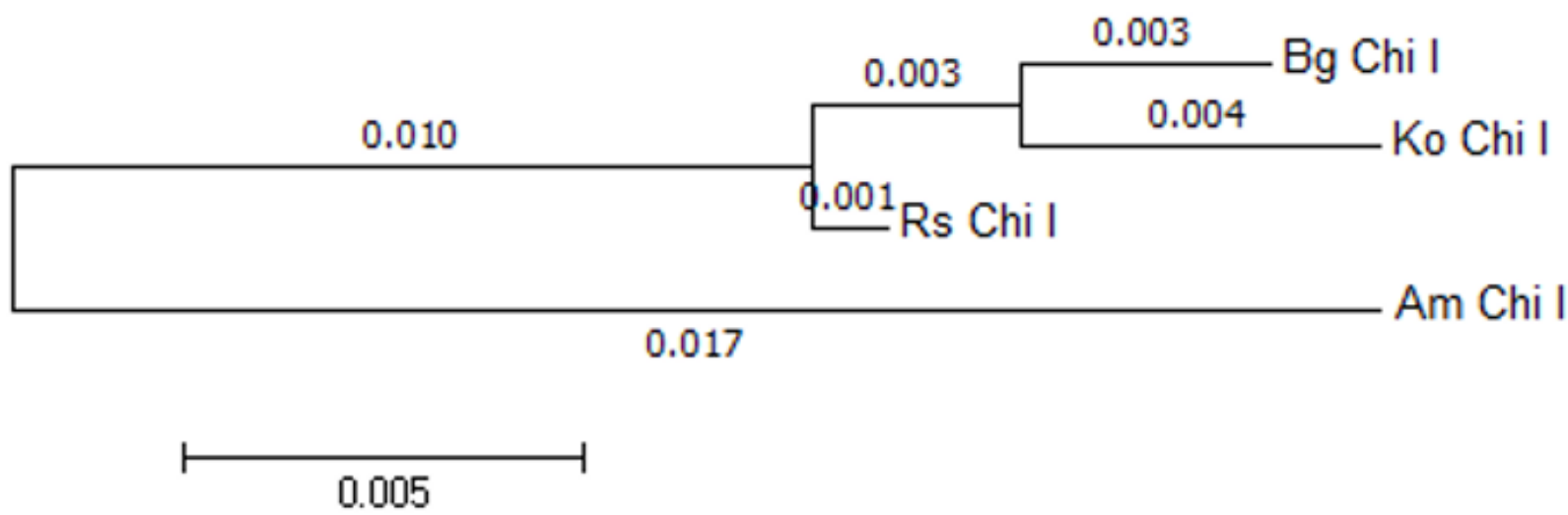

Figure 4

Similarity and phylogenetic analysis of amino acid sequence of four species chitinase genes 
A

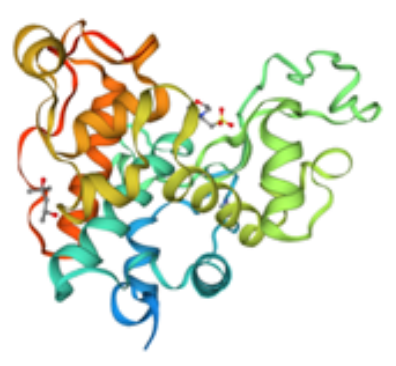

C

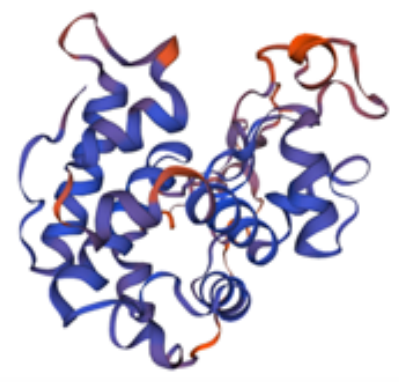

$E$

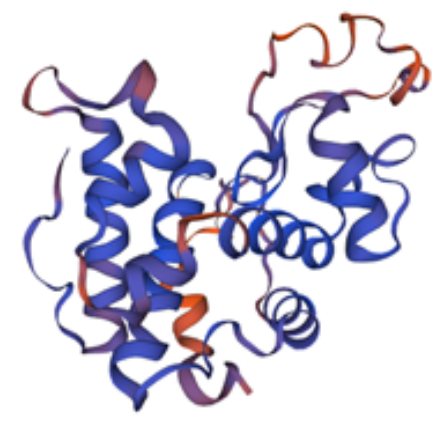

B
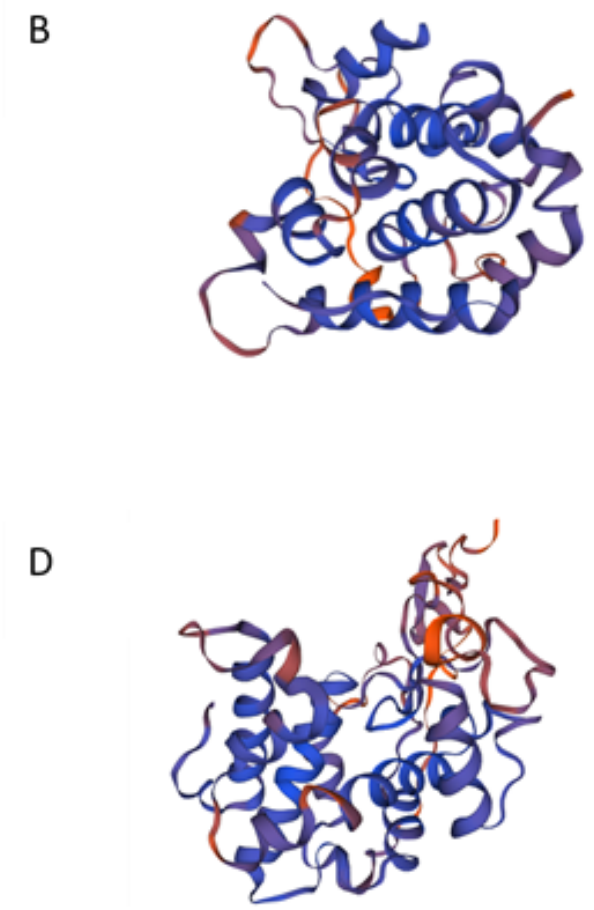

\section{Figure 5}

The molecular model of CHI I (A: Oryza sativa. B: Bruguiera gymnorrhiza. C: Kandelia obovate. D: Avicennia marina. E: Rhizophora stylosa). 


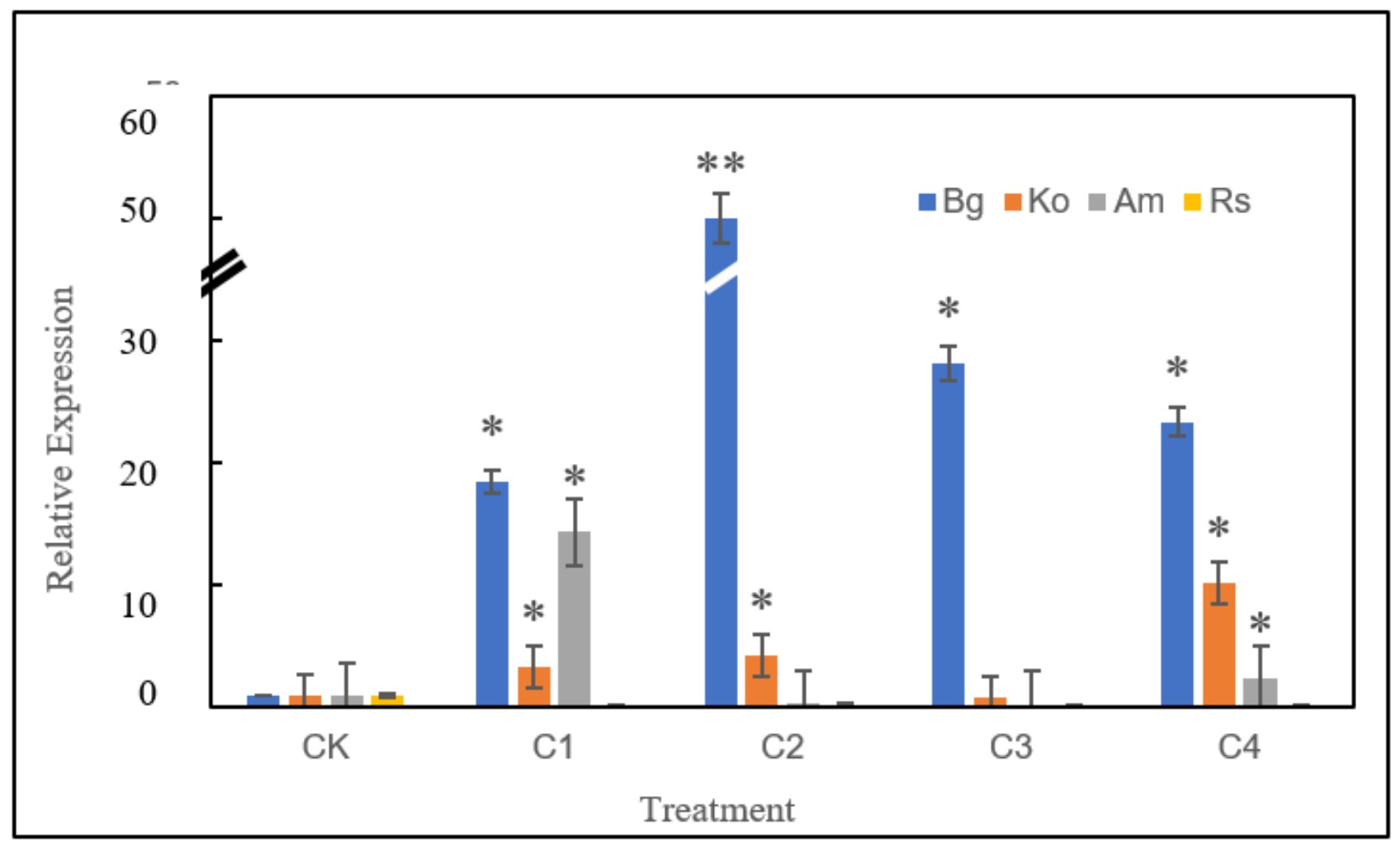

Figure 6

Expression of $\mathrm{CHI}$ gene in leaves of four species in response to heavy metal stresses using real-time quantitative PCR analysis. Significant difference is indicated by an asterisk $(P<0.05)$.

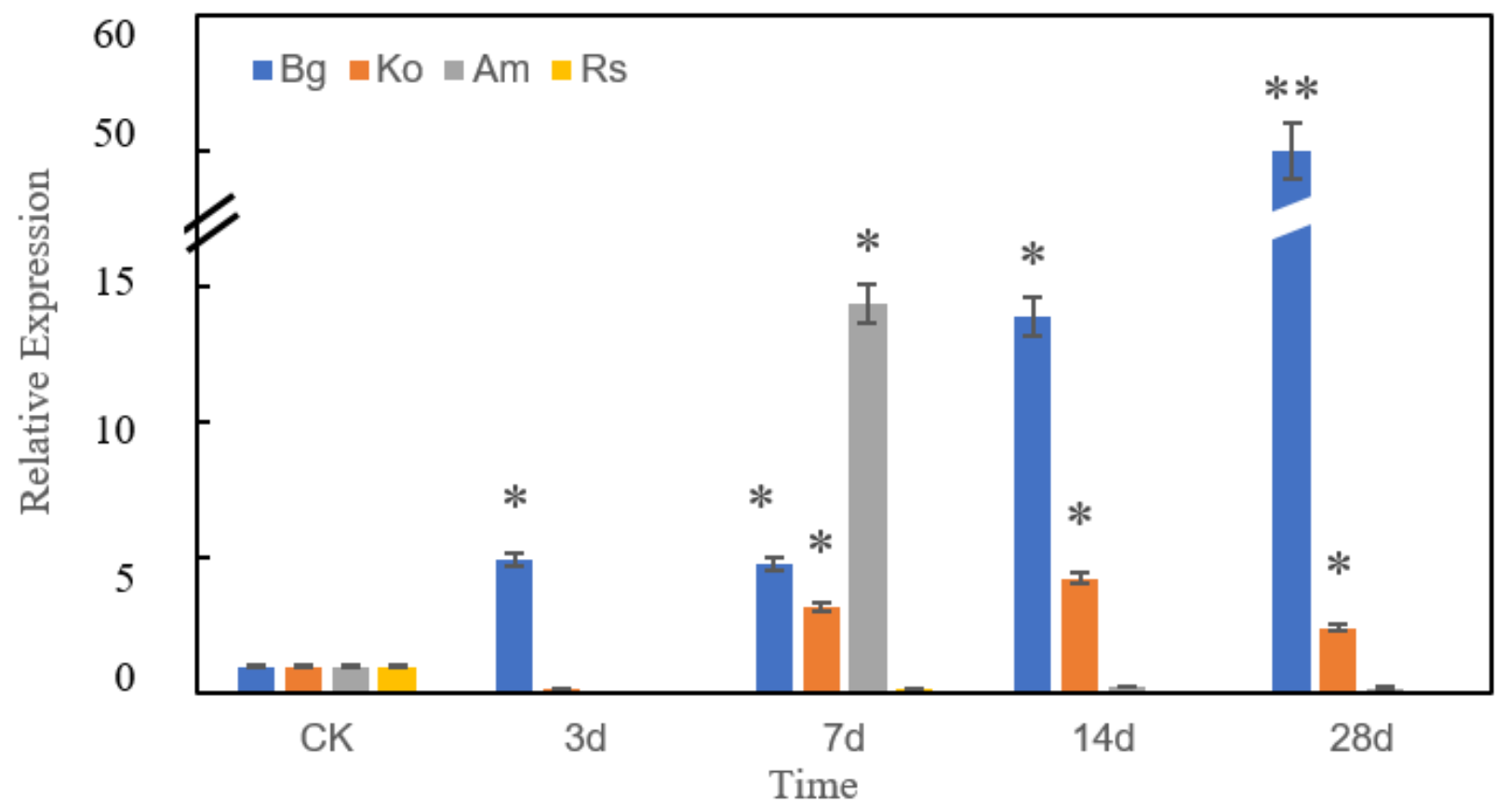

Figure 7 
The time effects of heavy metal exposure on the expression of CHI I mRNA in leaves of four mangrove species. Significant difference is indicated by an asterisk $(P<0.05)$.

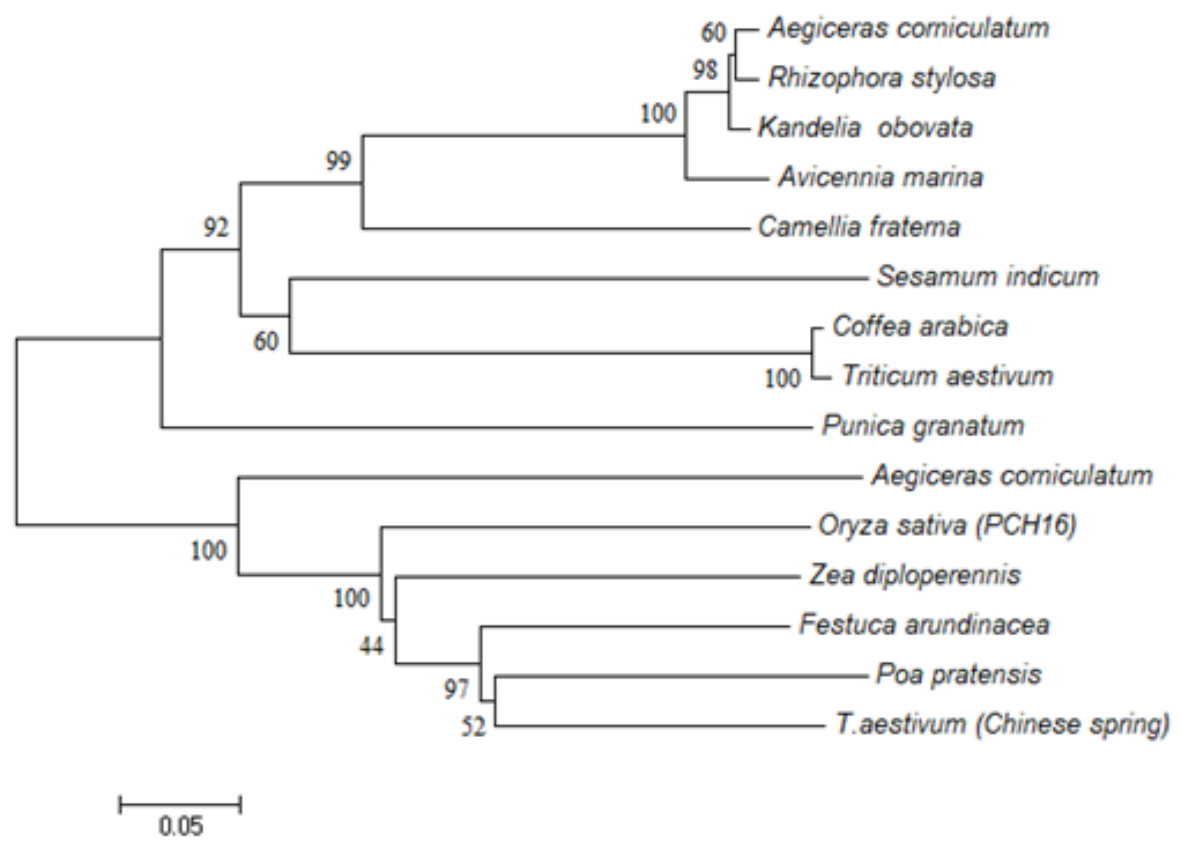

\section{Figure 8}

Phylogenetic tree of the $\mathrm{CHI}$ I. Multiple alignments of the sequences of $\mathrm{CHI} /$ and other selected plant chitinase- 1 were performed using MEGA 6.

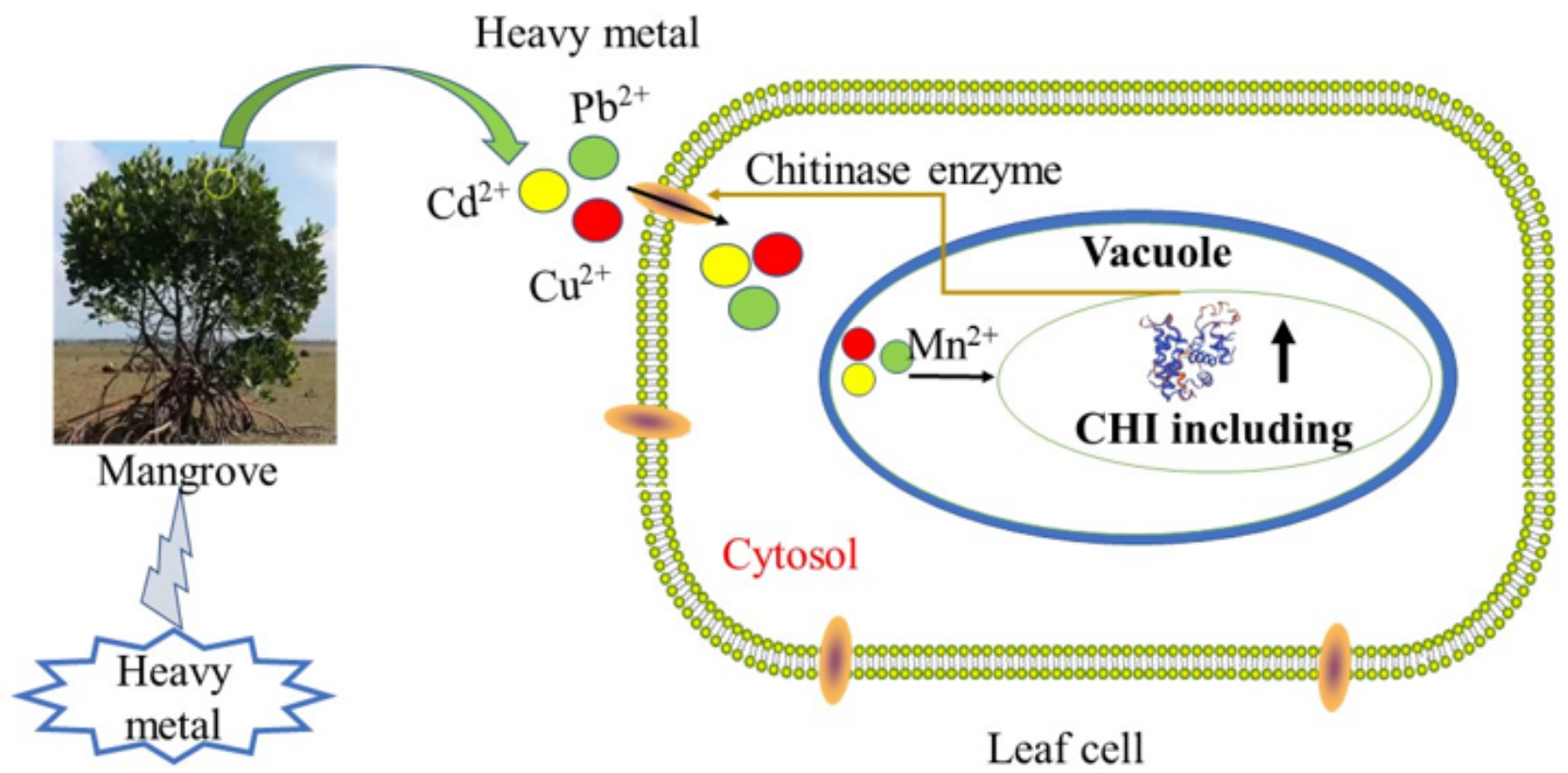

Figure 9 
A schematic diagram of the mechanism of chitinase resistance to heavy metals.

Page 19/19 